\title{
Lowalangi: From the name of an ethnic religious figure to the name of God
}

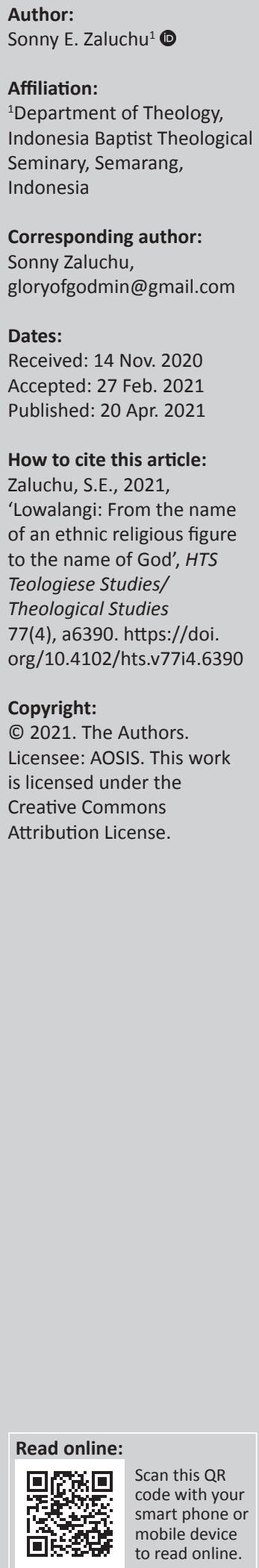

\begin{abstract}
This article shows the success of local cultural adaptation strategies in communicating the gospel to people of the Nias ethnicity in North Sumatra, Indonesia. This adaptation is the name Lowalangi, the name of the god of the pre-Christian era, to become the name of God, the creator and saviour of the world incarnated in the person of Jesus Christ. As a result, the use of this name was not limited to a translation process. Still, the whole concept of divinity for the Nias people was transferred and transformed into a Christian understanding. They know him as Lowalangi, have faith in him and pray to him in that name. The author uses a comparative analysis with other places in Indonesia. The author tries to establish parallelism with methods used elsewhere, assuming that the methods used tend to be the same.

Contribution: Churches and Christians in Nias are strengthened in their beliefs by praying and mentioning Lowalangi's name, which imparts the same faith quality as the biblical use of God's personal name. This adaptation can be a strategy for introducing the gospel in missiology and church planting in response to local culture as a wealth that cannot be negated. This research also has implications for the sociology of religion regarding the relationship between tradition and religious practice.
\end{abstract}

Keywords: adaptation; Nias ethnicity; God's name; reinterpretation; religion in culture.

\section{Introduction}

Introducing God's name into the local language is a challenge for missionaries who are spreading the gospel to new territories. On the one hand, God's personal name must still be introduced in its original form; on the other hand, missionaries must be able to make God's name easy to understand in the concept of thinking of the local community, which already has its own sociocultural construction. These two sides present difficulties, because the essence of God's name cannot change with place and time, but at the same time the local people, to whom the gospel is to be preached, often have a strong and established way of thinking. As a result, every missionary has to struggle with this conflict.

This is similar to what was done in Nias by Sundermann, a German evangelist as an RMG missionary who translated the Bible into the Nias language in 1896. Sundermann was the second Western missionary to come to Nias island. Apart from preaching the gospel, he founded a Bible school to produce Bible teachers from the Nias tribe himself. One of the challenges was to present Bibles that the Nias people could read in their native language. The translation project went on for years because of the difficulties in translating and adapting the Bible's technical concepts and terms into the Nias language. The work was finally finished and was given the name Soera Ni Amonio, literally translated as 'The Sacred Letter'. One of the successes of this translation was adapting pre-Christian tribal religious concepts into biblical terms and concepts. He used the name Lowalangi as the translation of God's name (Gulo 1983). As far as the author is aware, not much is known about how Sundermann did it. There has been very little research on this. However, it is very important to study the Sundermann method because the impact of his work was significant: the Nias people still use the term Lowalangi when pronouncing the name of God.

Previous research on this topic includes Dorkas Orienti Daeli's (2014) dissertation entitled Lowalangi dan Allah: Eradikasi Dualisme Entitas Allah pada Agama Kristen Suku Nias [Lowalangi and God: Dualist eradication of the entity of God in the Christian religion of the Nias ethnic group]. The conclusion of her dissertation is that the two names have become one in the Christian faith concept of the Nias ethnic group, where Lowalangi and God are understood as the same entity, although the background of the names is different (Daeli 2014). Another researcher who has written on this topic is Souisa (2019), whose article is titled Lowalangi sebagai Nama Allah 
[Lowalangi as the name of God]. According to him, the name Lowalangi was adopted by the Christian evangelists in Nias, and it has parallels to the name of the God in the Bible. This was done as an effort to introduce the identity of God into the social and religious structure of the Nias ethnic group, which had a strong pre-Christian tradition. Although rooted in tradition, Lowalangi has obtained a new meaning in Christianity as the highest name of God for Nias Christians. However, Daeli and Souisa have not yet focused on the translation process and have used deductive argumentation that the definition of Lowalangi has experienced some changes. This problem is explained by Jatmiko (2020), who states that technically, it can be seen as the process of equating the term Lowalangi with God's name. There was a process of adaptation and absorption here, so that the concept of God brought by the missionaries could be understood and accepted by the local community.

The research conducted by Hummel and Telaumbanua (2007) on the conversion of the Nias ethnic group to Christianity has not provided a sufficient picture of the process of transition of the definition of Lowalangi as God in the animist worldview to God in the Christian worldview, God incarnate in Jesus Christ. The research has only noted that the meaning of Lowalangi changed to God as the creator of heaven and earth. Even though it does not describe it clearly, the change shows an attempt at assimilation, so that the name Lowalangi gets a new meaning.

Other research results are similar. The document Pustaka Negeri Idano Mola in the archive of KITLV Leiden, written by Mangaraja Famahela Hia, as cited by Hammerle (ed. 2008), used the name Lowalangi interchangeably with God when telling the story of a battle between Lowalangi and Latura Danõ. Hammerle (ed. 2008) criticised this process for having political intentions. Hammerle analysed it as a new interpretation out of context; however, at that time the colonials wanted to ingratiate themselves with leaders such as the customary chief (Salawa Hada), the ethnic religious spiritual figure [Ere], village leaders (Salawa Banua) and the community rulers, called Tuhenõri (Koentjaraningrat 1993; Lase 1997). Thus, by using the name Lowalangi, the name for a local deity that existed before colonialism, the process of subduing the local population would be much easier.

Considering the above limitations, this article attempts to carry out a theoretical reconstruction of the process carried out in Nias by Sundermann.

\section{Methods}

In order to explain the process of adapting God's name to a local name, as occurred on Nias Island, the author conducted a comparative analysis with other places in Indonesia. Given the insufficient information available about this process in pre-Christian Nias, the author attempts to build parallelism with methods used elsewhere, on the assumption that the methods employed are likely to be the same. This is understandable because missionaries who arrive in Indonesia generally learn firstly about the local culture. Moreover, missionary activities in the 18th to 19th centuries in Indonesia were generally dominated by Western missionaries who probably had the same patron. They absorbed and adapted local cultural concepts to introduce Christian concepts.

A literature search was conducted using references from missionary records and literature by mission institutions. To make it more theoretical, the author uses references from contemporary writings, which must admittedly have a more scientific basis.

\section{Discussion}

\section{The origin of the Nias people}

In his research, the anthropologist Garang (2007) stated that the origin of the Nias people can be traced from the migration of a group of people coming from Vietnam and Thailand, and they finally arrived on Nias Island and became the permanent residents and the ancestors of the modern Nias people. Research conducted by Balai Arkeologi Medan [the Archaeological Office of Medan] provided evidence that a cave called Togi Ndrawa (Forestier et al. 2005) had first been a dwelling for ancient Nias humans 12000 years ago, with characteristics similar to the civilisation of Hoa Binh, a city in Vietnam. The deoxyribonucleic acid (DNA) research conducted by Van Oven et al. (2011) describes the Nias ethnic group as belonging to the Austronesian family of people. Archaeological findings have detected remnants of megalithic culture in Gomo. In an anthropological study conducted by Wiradnyana (2011), ancient heritages were found to be evenly distributed throughout Nias Island. Moreover, human life is interesting to study because the traditional culture is influential and permeates modern social life.

The Nias people prefer to explain their origin through mythology. Although there are several versions, almost all describe the dichotomy of heaven and earth. Heaven is considered to consist of several layers; the ninth layer is the highest layer and is called Teteholi Anaa (Lase 1997). The ruler of that place was Balugu Sirao, and he had two sons, namely Hia Walangi Sinada and Balugu Luo Mewona. During a competition, Hia Walangi Sinada became lost and was exiled to earth, descending at a place called Gomo. As Duha (2012) explained, the Nias people's ancestor descended from heaven equipped with life supports, such as a house, furniture, agricultural equipment, a number of plants and seeds, measurement tools and a variety of statues called $a d u$ [idols] in the Nias language.

Using mythology as the reference for an origin, according to Loeb (2013), is the main characteristic of communities in the Polynesian group. That type of community is typically rooted in the ancestor tradition and prefers to trace their origin up to the level of gods. In other words, mythology is influential in the cultural system and formation. Therefore, the 
contemporary Nias people are strongly influenced by tradition in their behaviour and life of the community, including their religious life.

\section{Lowalangi in the cosmology of the ethnic religion}

Lowalangi is actually a mythological concept of the ethnic religion but existed in Nias civilisation long before the arrival of Christianity. This concept was born from the beliefs of the ancient Nias people about the two brothers, Lowalangi and Latura Danõ (the elder; several separate manuscripts call him Nazuwadanõ). Suzuki (1979), an anthropologist who has published many studies on the Nias ethnic group, explained the differences between Lowalangi and Latura Danõ cosmologically. Latura Danõ, as the elder son, represents an entity staying in the underworld, is feminine and is the symbol of the lord of darkness. In contrast, his younger brother, Lowalangi, has a superior position as the ruler of heaven (the world above), is masculine and is the carrier of light. Both are connected in a cosmological dialectic between the world above and the underworld - the highest and lowest, heaven and earth influencing the social life.

Even the meaning of the term Lowalangi has expanded into daily use, and not only in the religious domain. Research by Hammerle (1996) discovered that the term Lowalangi is also used to describe respected people like parents, uncles, the nobility or counsellors. With a name considered to have the highest position in the cosmology, Lowalangi is very admired and respected as a god.

The cosmological structure in the Nias people's religious system is not only limited in religious practical scope but also integrated with the sociocultural space of the Nias people (Wiradnyana 2010). Hence, Lowalangi has a very important and strong place and is attached in the social practice of the Nias ethnic group. This is supported by the opinion of Esposito, Fasching and Lewis (2015), who state that Lowalangi has become an 'important reality' in all the structures of life. It is said that the term Lowalangi describes God according to the concept of the ancient Nias people, just like many other terms used by other religions in the world to illustrate an important reality in the collective value and group meaning. By applying this thought, the ancient Nias people are not atheist, but they are an ethnic group who believe in the Almighty 'up above' and believe that the transcendent power can incarnate into diverse material beings. This belief emerges in the narrations, concepts, symbols and mythology passed down traditionally and orally to every generation (Zazuli 2018). This is a feature of the polytheistic tradition and even leads to henotheism. As understood, henotheism is a transitional stage from polytheism to monotheism (Heiser 2008). Henotheism is based on the understanding that there is only one god who reigns in the world without denying other gods' existence. With this perspective, the pre-Christian understanding of the Nias people was henotheistic regarding the concept of Lowalangi.

\section{Imperative power of the ethnic religion}

A strong belief in myths, magic and holy things in a primitive community will become a resistance factor when a new religion is introduced (Kruyt 2008). This was what was experienced by the missionaries coming to Nias to spread the gospel (Gulo 1983).

This religious cosmology and cultural system that were mutually integrated became a resistance factor to the Western missionaries' effort to convert the community there to Christianity (Yung 2004). A similar experience happened with the ethnic religion of Kaharingan in Central Kalimantan, as described by Rusmanto (2018). Kaharingan Tua was considered as a local cultural product that they had to obey and need to be conquered by a new religion brought by the Western missionaries. Religions brought by missionaries are generally opposed because they erode the old religion's influence, which has long taken root in society. The previous religions that have grown up as local wisdom are consistently marginalised in the midst of the community that had maintained and nourished them.

A similar situation happened in Nias. According to the research by Hummel and Telaumbanua (2007), the missionaries were perceived as 'trying to eliminate everything considered as part of the old religion'. Lubis (2017) stated that those things occur because ethnic religions have imperative power in the cultural structure and life of the community. These ethnic religious teachings have already been integrated with the basic life values and worldview of the followers. Durkheim (2011) explained this matter by stating that primitive religions are considered capable of providing an explanation about the life's reality of humans that is actually very simple. This occurs because those primitive religions, more accurately called 'indigenous religions', have grown along with the community that gave birth to them. Thus, it is not surprising that a more advanced thinking is considered as failing to provide answers because of its complexity.

\section{Adaptive reinterpretation}

The reinterpretation of the name Lowalangi in the concept of the Nias ethnic group cannot be seen only in the context of the meaning changing. This process involves the entire conversion and the transition of the Nias people's belief system from an ethnic religion to Christianity. In his book entitled Keluar dari Agama Suku Masuk ke dalam Agama Kristen [From an ethnic religion into the Christian religion], Kruyt shared his experiences in introducing the Bible into the ancient cultural and religious system of the Poso people in Sulawesi. According to him, the concepts of ethnic religiosity there contain one belief system about the powers beyond humans. Thus, instead of choosing to become confrontational, the ethnic belief system just keeps on emerging and being 
highlighted in the frame of the Bible. As a result, new concepts have been born as the implementation of the relationship between the local culture and God through the interpretation process (Kruyt 2008).

As a missionary who brought the Bible to Nias, Sundermann seemed to realise that the Nias ethnic religion saw Christianity as a Western power coming from outside to conquer. Thus, there was strong resistance from the local community to maintain the tradition. Hence, what was Sundermann's strategy? Instead of bringing a foreign name, Sundermann in fact applied the name Lowalangi from the Nias ethnic concept to introduce God. Sundermann used a local name that already existed, had deep roots and was understandable to the people at that time. Sundermann used the name Lowalangi because the Nias people have long had a very strong, but unknown, 'figure'.

The choice was made not only to deal with linguistic problems but also to build a cultural bridge to introduce God the creator, saviour, full of love, who sent his only child as the saviour of the world, into the traditional ethnic religious system, which had rejected the new religion very strongly (Eliade 2002). Therefore, it can be understood why the missionaries chose the absorption or adaption approach, as Kruyt did in Poso (Niemandt 2010; Van den Toren \& Hoare 2015). Because the Nias people understood Lowalangi as an entity having divine power, God the creator and saviour was introduced as a similar concept. This is what was meant by Kruyt (2008) as adjustments based on a similar essence, or core concept. Kruyt asserted that the new religion (Christian) cannot show up to prove the incorrectness or lies of the ethnic religion, or even to go against or to mock it. On the contrary, from every teaching, the core is taken to become an entrance to introduce faith in and love of God. Simanjuntak (2016) added that tradition becomes part of the community cultural system elements, which have gone through the religious Christian process for hundreds of years. The religious values are considered parallel or mutually complement each other with the new religious belief. Simanjuntak (2016) called that 'similar essence'. Hence, it can be concluded that as in Poso, the reinterpretation of the name Lowalangi from the traditional understanding to a new understanding in the Christian religion was the result of the introduction of the Bible into the Nias cultural root itself. As a result, there has been a change in religious followers' orientation and personal perspective from the old way of life to the new one (Dy-Liacco et al. 2009). These changes include aspects of values, meaning, belief principles and faith reflection.

As explained above, the concept of similar essence from Simanjuntak (2016) and the strategy of 'taking the core' from Kruyt (2008) were practised by Paul the Apostle when visiting Athens, a religious town with a Hellenistic belief system that was very powerful. When witnessing that the town was full of statues of idols, Paul came to introduce Christianity (a new religion), not by fighting the local culture or mocking it. Paul interpreted the Greek belief system by using the worshipped statues as a cultural bridge:

Because while I was walking around your town and seeing your worshipped items, I met also an altar with the writing: To God the Unknown. What you worship without knowing it is what I inform you. (Ac 17:23)

Paul realised that those statues were part of the religious life. Therefore, the Greeks gave space to worship the unknown God. Paul made the adaptation of introducing God (Newman \& Nida 2008). Arnold (ed. 2002) explained that the Athenians had much respect for the gods, wanting their blessings and virtues. By erecting altars even to unknown deities, they convinced themselves that gods who had escaped recognition still received respect. Paul used the local Greek pagan religion's concept to identify the true God beyond their gods.

Weber (2019) once explained that the presence of a supernatural component in an ethnic religion is believed and plays a role in the animist faith system. This belief system has already been integrated and forms the community's culture. Sundermann managed to make a cultural adaptation. Besides opening the door to acceptance, the concept is easily understood, can be accepted and does not change the social system. To the present, the Nias people always mention the name Lowalangi in their prayers, but they refer to God, no longer the Lowalangi in the context of their ethnic ancestor religion. The reinterpretation does not change the symbols, buildings, signs or habits. What has happened is the transition of meaning and faith from the symbols, buildings, signs and habits into a new concept. Such success can become the model and strategy for every effort to introduce the Bible to the most remote ethnic groups in other areas, known to be resistant towards change. The fact that in several areas Christianity has inherited the previous religion's features is undeniable. It happens especially in communities where the ancient religious teachings have been absorbed so deeply so that they are hard to replace; even though they used to worship gods, now those gods have been replaced because of the reinterpretation process (Menzies 2014). This fact is revealed in several studies (Nyuyki \& Van Niekerk 2016 in Cameron; Sahay 2016 in India and Abe's [1997] research in Japan); they can be used as examples to conclude that mixing old religions with new religions as a syncretism cannot be avoided.

A syncretistic point of view can be used to complement this explanation. During the preaching of the gospel in the 1st century, when it came out of the area of Jerusalem, it entered new territory. It reached people who had been known as pagan and worshipers of the gods. Various teachings based on philosophy, such as Stoicism, Epicureanism and Gnosticism, developed (Bodrožić 2017; Logan 2017). Hellenism influenced people's lives (Helleman 2016). The impact can be seen in Paul's ministry. The Colossians felt that Christ was not sufficient to be the sole guide for salvation. People became tolerant of mixing Christian teachings with traditions, customs and even philosophical teachings. Paul rebuked them and said that they must 'walk in Him, have 
their roots and be built up in Him' (Col 2:7-9). Paul said that the main corridor of Christianity is only Christ. Compromise by utilising other sources cannot be justified (Keener 2014). The same phenomenon is revealed in the character of the Christians at Corinth. Even though they had become followers of Christ, they were still oriented to the old beliefs of Corinth, which was notorious for being pagan and obscene. For example, the act of enjoying food offered to idols during pagan temple celebrations (1 Cor 8:10,10:7) was vehemently opposed by Paul (Keener 2014). That is why syncretism in Christianity becomes dangerous when the preaching of the gospel makes adaptations that are too deep and powerful in order to communicate God's word through old religious concepts. Without maturity, the receiving community, who grew up in the old culture, believes the gospel on the one hand but still maintains the concept of customs, on the other. $\mathrm{Hu}$ (2015) said that religious syncretism is the mixture of old religious elements into a new religion. According to him, the transfer of elements from one religion to another without a change in the recipient religion's essential character is considered syncretism. Is this justified? Hu (2015) said that Mary (2011) also expressed the same indication, that Christianity cannot be separated from syncretism. A positive understanding must be developed, especially when viewed within the framework of inculturation as an integrative process for expressing the gospel in a particular culture. As long as the primary biblical meaning is not obscured, this is part of the mission strategy. In other words, Sundermann's attempt to use the name Lowalangi to replace God's name can be understood in the framework of inculturation.

\section{Conclusion}

From the above explanation, adaptive processes, like Sundermann's, have the essential meaning of introducing God's name to local people who already have a religious presupposition in their old beliefs. More than just a matter of translation, Sundermann's efforts have entirely changed the Nias people's divine concept. By adopting the name Lowalangi, the Nias tribe's understanding of God was reconstructed, moved and changed from the worldview of tribal religions into a Christian biblical concept. Lowalangi is now no longer seen as the name for the ruling deity in the heavens above, or an offering in the form of a statue, as worshiped by the pre-Christian Nias people's ancestors. The modern meaning refers to the name and person of the Lord of the Worlds, as revealed to Abraham, Isaac and Jacob. When the Nias people pray and mention Lowalangi, or read the Nias language Bible, where there is the same name, Lowalangi is understood and respected as a figure of God, Elohim. He is incarnate through the person of Jesus Christ, the saviour of the world. In the entire religious system and the Nias people's sociocultural life, Lowalangi is understood as a holy, noble and honourable name. It cannot be mentioned carelessly but only through prayer, praise, reading of holy books and other spiritual rituals. The generation of people on Nias born in the Christian era and who have nothing to do with ancestral religions only understand that God is the creator of the universe, which is contained in the Book of Genesis, named
Lowalangi in the Nias language. Sundermann succeeded in rendering God's name into the Nias language but introduced the complete person of God into the Nias cosmological concept based on Christian principles.

In every target area of evangelism, Christianity always intersects with a local culture that has been deeply rooted over generations. This effort can be exemplified as a strategy for communicating a good and acceptable gospel to the public without experiencing confrontation. Aspects of local cultures such as concepts, symbols, rituals and other cultural wisdom tools can be absorbed and accepted as a part of Christianity as long as the Bible truth is not compromised.

This research can be continued with a broader scope to see to what extent the influence of the indigenous culture of the Nias tribe in Christianity has adapted there. The same research can be applied to other cultural spheres around the world.

\section{Acknowledgements}

The author would like to thank Fotarisman Zaluchu, Ph.D., for reading the manuscript and providing corrections to sharpen the article's analysis. The author also would like to thank Dr Robinson Rimun, President of the Indonesia Baptist Theological Seminary, for support in funding this research.

\section{Competing interests}

The author declares that no competing interest exists.

\section{Author's contributions}

I declare that I am the sole author of this research article.

\section{Ethical consideration}

This article followed all ethical standards for a research without direct contact with human or animal subjects.

\section{Funding information}

Funding for this research came from the Indonesian Baptist Theological Seminar. It was derived from the lecturer research budget and as such, this work is independent, not for commercial interests. The author has declared that there is no conflict of interest between the institution and himself in terms of funding and research material.

\section{Data availability}

Data sharing is not applicable to this article as no new data were created or analysed in this study.

\section{Disclaimer}

All ideas, views, and conclusions and statements in this article are the responsibility of the author personally and have no connection with the funding institution and the place where the author works as a lecturer. 


\section{References}

Abe, M., 1997, 'Shinto and Buddhism: The two major religions of Japan', in S. Heine (ed.), Zen and comparative studies, pp. 221-31, London, Palgrave Macmillan UK. https://doi.org/10.1057/9780230375994_16.

Arnold, C.E. (ed.), 2002, Zondervan Illustrated Bible Backgrounds Commentary Volume 2, Zondervan, Grand Rapids, MI.

Bodrožić, I., 2017, 'Gnosis and gnosticism: Problems of terminology and dualism as the most important characteristic', Crkva u svijetu 52(2), 171-194.

Daeli, D.O., 2014, 'Lowalangi dan Allah: Eradikasi Dualisme Entitas Allah pada Agama Kristen Suku Nias' [Lowalangi and god: Eradication of the dualism of the entity of god in ethnic groups on Nias Island], PhD thesis, Sekolah Tinggi Theologia Paulus, Medan.

Duha, N., 2012, Omo Niha: Perahu Darat di Pulau Bergoyang [Omo Niha: Nias ethnic traditional house], Museum Pusaka Nias, Gunungsitoli, Nias.

Durkheim, E., 2011, The elementary form of the religious life, IRCiSoD, Yogyakarta.

Dy-Liacco, G.S., Piedmont, R.L., Murray-Swank, N.A., Rodgerson, T.E. \& Sherman, M.F., 2009, 'Spirituality and religiosity as cross-cultural aspects of human experience' Psychology of Religion and Spirituality 1(1), 35-52. https://doi.org/10.1037/ a0014937

Eliade, M., 2002, Sakral dan Profan [The sacred and the profane], 1st edn., Fajar Pustaka Baru, Yogyakarta.

Esposito, J.L., Fasching, D.J. \& Lewis, T., 2015, World religion today-Agama-Agama di Dunia Dewasa Ini, 4th edn., Kompas Gramedia, Jakarta.

Forestier, H., Simanjuntak, T., Guillaud, D., Driwantoro, D., Wiradnyana, K., Siregar, D. et al., 2005, 'Le site de Tögi Ndrawa, île de Nias, Sumatra nord: Les premières traces d'une occupation hoabinhienne en grotte en Indonésie', Comptes Rendus Palevol 4(8), 727-733. https://doi.org/10.1016/j.crpv.2005.08.004

Garang, P.J., 2007, Nias Membangun Harapan Menapak Masa Depan: Studi tentang Perubahan Sosial dan Kultural [Nias building hopes for the future: A study on social and cultural change], Yayasan Tanggul Bencana Indonesia, Jakarta.

Gulo, W., 1983, Benih yang Tumbuh - Sejarah Gereja BNKP Nias Volume 13 [A growing seed - History of the Nias BNKP Church Volume 13], LPLG-BNKP, Gunungsitoli.

Hammerle, J.M., 1996, Ritus Perang Harimau [Tiger war rites in Nias Island], Museum Pusaka Nias, Gunungsitoli, Nias.

Hammerle, J.M. (ed.), 2008, Tuturan Tiga Sosok Nias [The speech of the three Nias figures], 1st edn., Museum Pusaka Nias, Gunungsitoli.

Heiser, M.S., 2008, 'Monotheism, Polytheism, Monolatry, or Henotheism? Toward an Assessment of Divine Plurality in the Hebrew Bible', Bulletin for Biblical Research 18(1), 130.

Helleman, W.E., 2016, 'The "Triumph" of Hellenization in early Christianity', in L. Sanneh, M.J. McClymond (eds.), The Wiley Blackwell Companion to World Christianity, pp. 32-42, Wiley, Hoboken, NJ. https://doi.org/10.1002/ 9781118556115.ch3

Hu, D.A., 2015, Syncretism, New Dictionary of Theology, vol. 3, p. 251, SAAT Publishing, Malang.

Hummel, U. \& Telaumbanua, T., 2007, 'Cross and Adu: A socio-historical study on the encounter between Christianity and the indigenous culture on Nias and the Batu Islands, Indonesia (1865-1965)', PhD thesis, Universiteit Utrecht, Nederlands.

Jatmiko, B., 2020, 'Kajian Onomastika Teks Perjanjian Baru mengenai Transmisi Nama Diri di dalam Alkitab' [Onomastic study of the text of the New Testament concerning the transmission of names in the Bible], PASCA : Jurnal Teologi dan Pendidikan Agama Kristen 16(1), 40-49. https://doi.org/10.46494/psc. v16i1.81

Keener, C.S., 2014, The IVP Bible background commentary - New Testament, 2nd edn. IVP Academic, Downers Grove, IL.

Koentjaraningrat, 1993, Manusia dan Kebudayaan Indonesia [The peoples and Indonesian culture], 13th edn., Djambatan, Bandung.

Kruyt, A.C., 2008, Keluar dari Agama Suku Masuk ke Agama Kristen [Out of tribal religion to Christianity], 2nd edn., BPK Gunung Mulia, Jakarta.
Lase, P., 1997, Menyibak Agama Suku Nias [Uncovering the religion of the Nias Ethnic], Agiamedia, Bandung.

Loeb, E.M., 2013, Sumatera: Sejarah dan Masyarakatnya [Sumatera: Its history and people], Penerbit OMBAK, Yogyakarta.

Logan, A.H.B., 2017, 'Gnosticism' in P.F. Esler (ed.), The Early Christian world, 2nd edn., pp. 850-866, Routledge, New York. https://doi.org/10.4324/9781315165837

Lubis, R., 2017, Agama dan Perdamaian - Landasan, Tujuan dan Realitas Kehidupan Beragama di Indonesia [Religion and peace - Foundations, goals and realities of religious life in Indonesia], Gramedia Pustaka Utama, Jakarta.

Mary, B.D., 2011, 'Inculturation or Syncretism: New Wine in New Wineskin', Studia Philosophica et Theologica 11(2), 171-186, viewed n.d., from http://ejournal. stftws.ac.id/index.php/spet/article/view/69.

Menzies, A., 2014, Sejarah Agama Agama - Studi Sejarah, Karakteristik dan Praktik Agama-Agama Besar di Dunia [History of Religion: A Sketch of Primitive Religious Agama-Agama Besar di Dunia [History of Religion: A Sketch of Primitive Religious
Beliefs and Practices, and of the Origin and Character of Great Systems] in A. Koliq (ed.), 1st edn., FORUM Publishing, Yogyakarta.

Newman, B.M. \& Nida, E.A., 2008, Pedoman Penafsiran Alkitab: Kisah Para Rasul [Guidelines for Bible interpretation: The Book of Acts], 1st edn., Lembaga Alkitab Indonesia, Jakarta.

Niemandt, C.J.P., 2010, 'Acts for today's missional church', HTS Teologiese Studies / Theological Studies 66(1), a336. https://doi.org/10.4102/hts.v66i1.336

Nyuyki, P.S. \& Van Niekerk, A., 2016, 'Syncretism and inculturation in the Nso' context of Cameroon', Stellenbosch Theological Journal 2(2), 381-400. https://doi. org/10.17570/stj.2016.v2n2.a18

Rusmanto, J., 2018, 'Fenomena Agama Tua di Kalimantan Tengah: Makna Agama menurut Kepercayaan Kaharingan Tua' [Old religious phenomenon in central Kalimantan: The meaning of religion according to the Old Kaharingan Religion], in M. Farid, M. Adib (eds.), Fenomenologi Dalam Penelitian Sosial [Phenomenology in social research], 1st edn., pp. 165-177, Prenada Media Group, Jakarta.

Sahay, V.S., 2016, 'Syncretism in India: A reality or an unreality?', The Oriental Anthropologist: A Bi-annual International Journal of the Science of Man 16(1), 17-25. https://doi.org/10.1177/0976343020160102

Simanjuntak, B.A., 2016, Tradisi, Agama, Dan Akseptasi Modernisasi Pada Masyarakat Pedesaan Jawa [Traditions, religion, and modernization acceptances in Javanese rural peoples], Yayasan Pustaka Obor Indonesia, Jakarta.

Souisa, D., 2019, Lowalangi Sebagai Nama Allah [Lowalangi as the name of God] SUNDERMANN: Jurnal Ilmiah Teologi, Pendidikan, Sains, Humaniora Dan Kebudayaan 9, no. 6, pp. 1-20, Gunungsitoli, viewed n.d., from https://www. Kebudayaan 9, no. 6, pp. 1-20, Gunungsitoli, viewed n.d., from https://ww
researchgate.net/publication/335189559_Lowalangi_Sebagai_Nama_Allah.

Suzuki, P.T., 1979, 'The archaeological remains of Hiligowe, Nias (Indonesia) decoded', Antropos 74(1/2), 214-218.

Van den Toren, B. \& Hoare, L., 2015, 'Evangelicals and contextual theology: Lessons from missiology for theological reflection', Practical Theology 8(2), 77-98. https:// doi.org/10.1179/1756074815Y.0000000008

Van Oven, M., Hammerle, J.M., Van Schoor, M., Kushnick, G., Pennekamp, P., Zega, I. et al., 2011, 'Unexpected Island effects at an extreme: Reduced Y chromosome and mitochondrial DNA diversity in Nias', Molecular Biology and Evolution 28(4) 1349-1361. https://doi.org/10.1093/molbev/msq300

Weber, M., 2019, Sosiologi Agama [The sociology of religion], 1st edn., IRCiSoD, Yogyakarta.

Wiradnyana, K., 2010, Legitimasi Kekuasaan Pada Kebudayaan Nias [The legitimacy of power in Nias culture], Yayasan Pustaka Obor Indonesia, Jakarta.

Wiradnyana, K., 2011, Pra Sejarah Sumatera Bagian Utara: Kontribusinya pada Kebudayaan Kini [Prehistory of Northern Sumatra: Its contribution to present culture], Yayasan Pustaka Obor Indonesia, Jakarta.

Yung, H., 2004, Mangga atau Pisang? Sebuah Upaya Pencaran Teologi Kristen Asia yang Autentik [Mangoes or bananas? The quest for an Autentic Asian Christian Theology], 1st edn., Literatur Perkantas, Jakarta.

Zazuli, M., 2018, Sejarah Agama Manusia - Ikhtisar Agama-Agama, Mitolog dan Ajaran Metafisika Selama Lebih dari 10.000 Tahun [The history of human religions - An overview of religions, mythology and metaphysical for over 10,000 years], NARASI, Yogyakarta: Penerbit Narasi, 2018. 